\title{
Ethylene spray influences flowering of the Chilean bromeliad Fascicularia bicolor
}

\author{
Influencia de etileno en aerosol en la floración \\ de la bromeliácea chilena Fascicularia bicolor
}

Flavia Schiappacasse ${ }^{*}$, Claudia Moggia ${ }^{1}$, M. Paulina Rojas ${ }^{1}$ and Mónica Musalem ${ }^{2}$

\begin{abstract}
Chilean nurseries make important efforts to develop new native crops for landscaping, with emphasis on species suitable for water-saving conditions. Bromeliads are naturally adapted to low water soil conditions; the genus Puya is widely used as a garden plant. Worldwide, commercial bromeliads are forced to bloom by treating them with ethylene, either as a gas or liquid preparation. The family Bromeliaceae in Chile includes six genera with 24 species and five subspecies; the cultivated species are sold in nurseries mainly in the vegetative stage, and ethylene has not been tested to promote flowering.

The capacity of ethylene to promote flowering in Fascicularia bicolor was investigated in a nursery near Santiago (33'21'13" SL and $70^{\circ} 41^{\prime} 26^{\prime}$ WL) by spraying plants growing under a shading net or in a cool greenhouse with Ethylen ${ }^{\circledR} 48 \mathrm{SL}\left(0,2.5 \mathrm{ml} \mathrm{L}{ }^{-1}\right.$ or $5 \mathrm{ml}$ $\mathrm{L}^{-1}$ ethephon) in autumn, 2012. A similar experiment was conducted by spraying in the middle of the winter, using different plants growing in the open with full sun and under a shading net with constant shade or with morning light, testing 0 and $2.5 \mathrm{ml} \mathrm{L}^{-1}$ ethephon. Untreated plants did not show any change in phenology, either in the autumn or winter spraying times. After some months all autumn-treated plants showed the bright red color that precedes flowering, although not all plants reached anthesis. The winter-treated plants did not turn red, but flowering was $100 \%$ after four months.
\end{abstract}

Key words: flowering, ethylene, Ethylen®, Bromeliaceae.

\section{RESUMEN}

Los viveros chilenos hacen importantes esfuerzos para desarrollar nuevas especies nativas para su uso en paisajismo, con énfasis en especies adecuadas para condiciones de baja disponibilidad hídrica. Las bromeliáceas están naturalmente adaptadas a condiciones de bajo nivel de humedad en el suelo, siendo el género Puya ampliamente utilizado como planta de jardín.

A nivel mundial, a las bromeliáceas se las fuerza a florecer tratándolas con etileno, ya sea en forma de gas o en forma líquida. La familia Bromeliaceae en Chile incluye seis géneros con 24 especies y cinco subespecies. Las especies cultivadas se venden en viveros principalmente en estado vegetativo, y no se ha probado el uso de etileno para promover la floración.

La capacidad del etileno de promover la floración en Fascicularia bicolor subsp. bicolor, en adelante Fascicularia bicolor fue

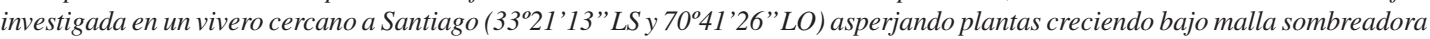
o bajo invernadero frío, con Ethylen ${ }^{\circ} 48 \mathrm{SL}\left(0,2,5 \mathrm{ml} \mathrm{L} \mathrm{L}^{-1}\right.$ o $5 \mathrm{ml} \mathrm{L} \mathrm{L}^{-1}$ de ethephon) en el otoño de 2012. Un experimento similar se realizó asperjando, en medio del invierno, plantas creciendo al aire libre bajo pleno sol, o bajo malla sombreadora con sombra permanente o recibiendo luz matinal, probando 0 y $2,5 \mathrm{ml} \mathrm{L} \mathrm{L}^{-1}$ de ethephon.

Las plantas que no recibieron etileno no mostraron ningún cambio fenológico, ni en las asperjadas en otoño ni en las asperjadas en invierno. Todas las plantas asperjadas con etileno en otoño, después de algunos meses, mostraron el color rojo brillante que precede la floración, aunque posteriormente no todas las plantas florecieron. Las plantas asperjadas con etileno en invierno no mostraron el color rojo; sin embargo, florecieron en un 100\% después de cuatro meses.

Palabras clave: Floración, etileno, Ethylen $®$, Bromeliaceae.

\section{Introduction}

Plants in the family Bromeliaceae show different adaptations to xerophitic conditions. The leaves are long, stiff, typically grouped at the base of the plant in rosettes, and have peltate scales or trichomas that give a greyish appearance to the plant. Most of the species are epiphytic; some are terrestrial. The flowers are mostly bisexual with 3 sepals and 3 petals, often very showy or with very attractive colored bracts

\footnotetext{
1 Facultad de Ciencias Agrarias, Universidad de Talca, Casilla 747, Talca, Chile.

2 Vivero y Jardín Pumahuida, Carretera General San Martín 7021, Santiago, Chile.

* Corresponding Autor: fschiap@utalca.cl
}

Fecha de Recepción: 19 Abril, 2016.

Fecha de Aceptación: 4 Octubre, 2016.

DOI: $10.4067 / \mathrm{S} 0718-34292016005000027$ 
arranged in inflorescences (L.H. Bailey Hortorium, 1976). Many genera are used commercially as potted plants, including Aechmea, Ananas, Billbergia, Cryptanthus, Guzmania, Neoregelia, Nidularium, Tillandsia and Vriesea (Black and Dehgan, 1993). The plants are especially charming when flowering begins; this process may be triggered by treatment with ethylene.

Chile is home to six genera of Bromeliaceae: Deuterochonia, Fascicularia, Greigia, Ochagavia, Puya and Tillandsia, totalling 23 species, 2 subspecies and 4 varieties (Zizka et al., 2009). Fascicularia bicolor (Ruiz \& Pav.), endemic to Chile, belongs to the subfamily Bromelioideae, which also includes Aechmea, Ananas, and Billbergia, among others. Two subspecies are recognized: F. bicolor subsp. bicolor and F.b. subsp. canaliculata. It is found along the coast, as a terrestrial plant on rocks or epiphytic on trees. The narrow leaves with thorny borders, can reach $50 \mathrm{~cm}$ in length. The inflorescence consists of 20-40 blue tubular flowers with yellow stamens, sorrounded by bracts that are longer than the flowers. During flowering, the leaves that surround the inflorescence turn red, giving the plant a very appealing appearance. Grown from seed it will flower after 5-6 years, but when propagated from offshoots flowering occurs in the first or second year (Riedemann and Aldunate, 2011).

Ornamental bromeliads are considered easy to grow foliage plants and are used in pots or planters, and as landscape plants in frost-free areas. Some species have appealing inflorescences; these are exposed to ethylene to induce flowering. Ethylene is a plant hormone that is a gas under normal pressure and temperature conditions. Etephon (2-Chloroethane Phosphonic Acid) is the best known ethylene releaser. It is applied in an acqueus solution that is absorbed and transported into the plant and will trigger the flowering process in bromeliads (Taiz \& Zeiger, 2006). There are different commercial products with ethephon as active ingredient. The recommended dose is $2.5 \mathrm{ml} \mathrm{L}^{-1}$ ethephon for most bromeliad varieties, spraying until the foliage is wet, but not until runoff (this dose was found in 2012 under the label of Florel ${ }^{\circledR}$, a product widely used in floriculture, in the site www.southernag. com/docs/labels_msds/florel.pdf).

Chilean bromeliads of different genera are commercialized in the local market, mainly in the vegetative stage. It has been observed that plants in the reproductive stage are strongly preferred by consumers. Ethylene has not been tested to induce flowering in those plants. The aim of this study was to determine if ethylene promoted flowering in Fascicularia bicolor plants of flowering size, using the general recommended dosage for other bromeliads under different ambient conditions.

\section{Materials and Methods}

Two experiments were performed, one in autumn 2012 and the other in winter of the same year, in a nursery located in an area with Mediterranean climate $\left(33^{\circ} 21\right.$ ' $13^{\prime \prime}$ SL and $\left.70^{\circ} 41^{\prime 2} 26^{\prime \prime} \mathrm{WL}\right)$. The 2012 meteorological data from the Dirección Meteorológica de Chile recorded an average annual temperature of $15^{\circ} \mathrm{C}$ and annual rainfall of $166 \mathrm{~mm}$ (Dirección Meteorológica de Chile, 2013). Recorded temperature data are shown in Figure 2 and 3.

All plants had 2-5 growing points or "heads", and had been propagated through offsets. The substrate mix was compost $61 \%$, soil $22 \%$, and sand $17 \%$. The plants were grown under a $65 \%$ shading net before the experiments started. The shading nets used during the experiments were also $65 \%$ shade. The plants were sprayed with ethephon; Ethylen ${ }^{\circledR}$ 48 SL (Agrícola Nacional S.A.C.I., distributed by ANASAC) was used as the ethephon source.

Degree days over $10{ }^{\circ} \mathrm{C}$ were recorded to follow phenology changes. A phenology scale was developed to define the most important visual plant stages (Figure 1). A radiometer Li-189 (LICOR, USA) was used to record instantaneous light intensity at plant level on a clear sky day (November 7,2012 ), showing that at 9:00, 12:00 and 16:00, PAR was higher under the shading net (more than $800 \mu \mathrm{mol} \mathrm{m}-2 \mathrm{~s}^{-1}$ ) than in the greenhouse (around $200 \mu \mathrm{mol} \mathrm{m}^{-2} \mathrm{~s}^{-1}$ ).

The variables were arranged in a random design. Light conditions and seasons were analyzed separately. The Tukey test was applied when significant differences were found. The data from the phenology stages were analyzed by the nonparametric Kruskal-Wallis test.

\section{Autumn experiment}

The plants used for this experiment were 4 years old, in bags $20 \mathrm{~cm}$ in diameter. Plant height was $30-40 \mathrm{~cm}$ and plant diameter measured in the basal 


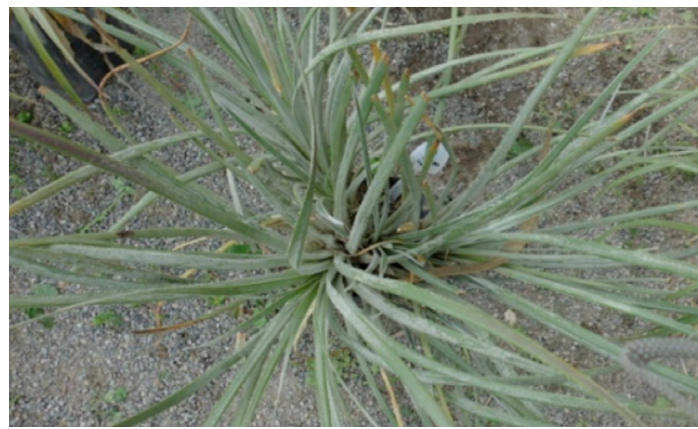

Stage 1.

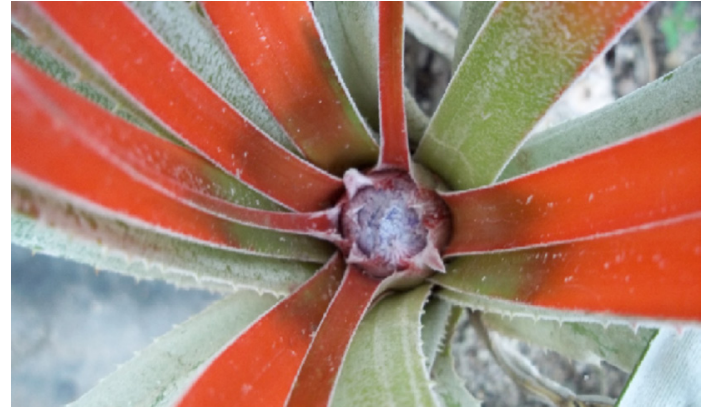

Stage 2.

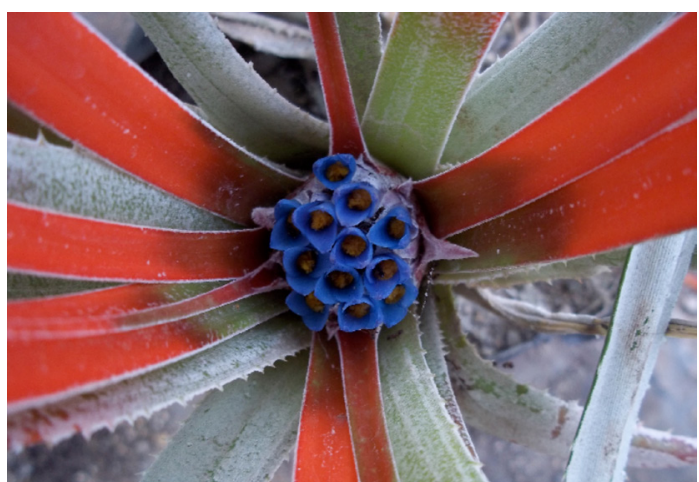

Stage 4.

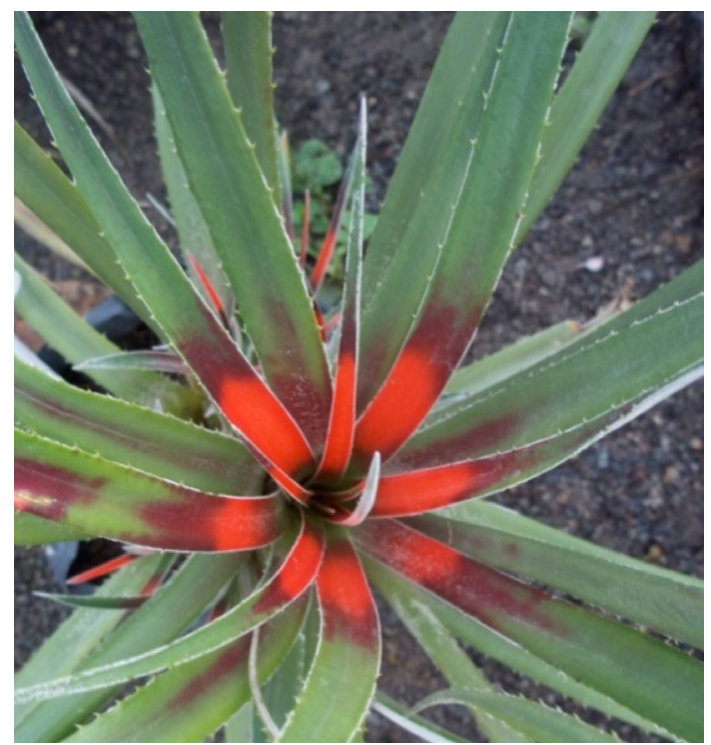

Stage 3 .

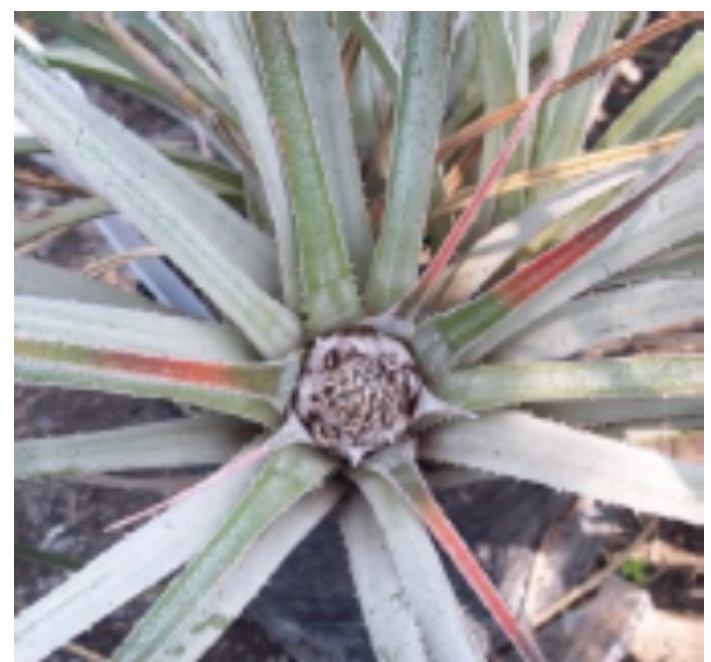

Stage 5 .

Figure 1. Development stages in the Fascicularia bicolor flowering process: Stage 1: no change; Stage 2: inner leaves turn red; Stage 3: visible flower bud; Stage 4: anthesis; Stage 5: senescence of flower bud.

part of the plant was $8 \mathrm{~cm}$. The plants were sprayed on April 3 with ethephon. Three concentrations were applied: control (unsprayed); $2.5 \mathrm{ml} \mathrm{L}^{-1}$ ethephon and $5 \mathrm{ml} \mathrm{L}^{-1}$ ethephon. After spraying, the plants were placed under two different conditions: inside a cool polyethylene greenhouse ( $0.2 \mathrm{~mm}$ thickness), or outdoors under a shading net, in a border where they received morning sunlight. In each condition, three plants were used per treatment, and a random experimental design was used.

\section{Winter experiment}

The plants used were 6 years old, in pots $32 \mathrm{~cm}$ in diameter. Two treatments were used: control (unsprayed), and $2.5 \mathrm{ml} \mathrm{L}^{-1}$ ethephon, spraying on August 31. The treated plants were placed in full sun and under a shading net in two locations; in the center of the shading net, where plants did not receive direct sunlight, and in a border, where plants received morning sunlight. 


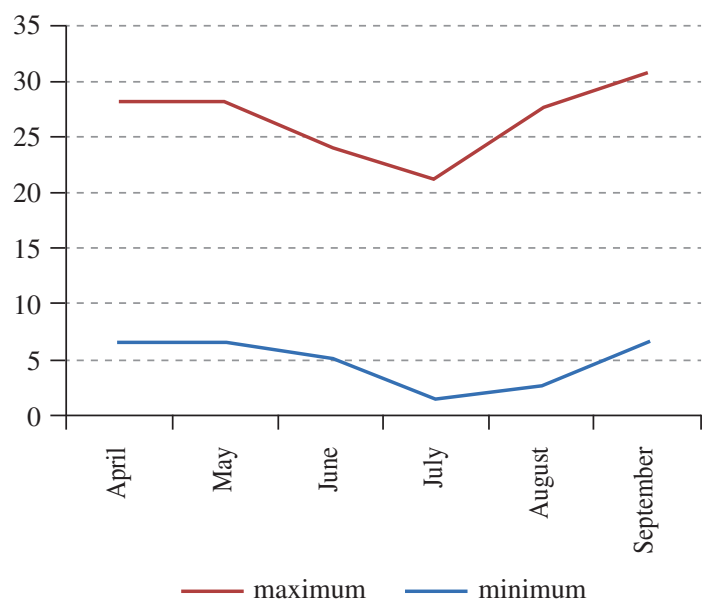

Figure 2. Maximum and minimum temperatures recorded in the greenhouse.

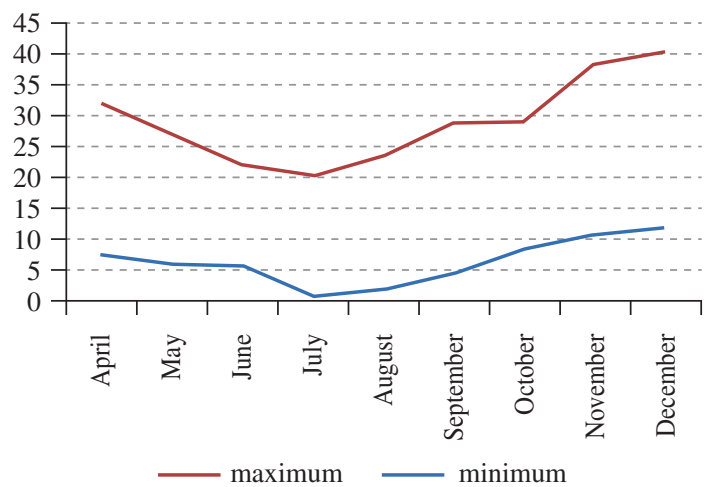

Figure 3. Maximum and minimum temperatures recorded under the shading net.
Six plants were used per treatment, under a random experimental design.

\section{Results}

\section{Autumn experiment}

The unsprayed plants did not show any change in phenology. In contrast, all the ethephon-treated plants showed a bright red color in the leaves close to the plant center more than 3 months after spraying. The degree days accumulated from spraying time until the color change were 280 and 258, under greenhouse (August) or shading net (June/July), respectively. These results suggest that the plant needs low temperatures to change the leaves to the red color, and that the process tookaking longer in the greenhouse where temperatures were slightly higher. Anthesis was observed in October (Tables 1 and 2), with accumulated degree days of 558 and 467 under greenhouse and shading net, respectively.

The time to flowering is less in common ornamental bromeliads, from six weeks (Aechmea) to eight weeks (Vriesea) (Clemson Extension, 1995). The delay in this case could be due to genetics or to the fact that the Fascicularia plants were placed inside an unheated greenhouse or in the open under a shading net, while ornamental bromeliads are kept in heated greenhouses. Only one out of nine plants flowered in the greenhouse when sprayed with $2.5 \mathrm{ml} \mathrm{L}^{-1}$ ethephon, and flowering increased to $44.4 \%$ in plants sprayed with $5 \mathrm{ml} \mathrm{L}^{-1}$.

Table 1. Development stages of Fascicularia bicolor plants kept under shading net or under greenhouse in Santiago, sprayed with 0, 2.5 or $5 \mathrm{ml} \mathrm{L}^{-1}$ ethephon on April 3, 2012.

\begin{tabular}{|c|c|c|c|c|c|c|c|}
\hline & Ethephon spray $\left(\mathrm{ml} \mathrm{L}^{-1}\right)$ & August 2 & August 16 & August 30 & September 28 & October 19 & October 30 \\
\hline \multirow{4}{*}{ Shading net } & 0 & $1 \mathrm{a}$ & 1a & 1a & $1 \mathrm{a}$ & $1 \mathrm{a}$ & $1 \mathrm{a}$ \\
\hline & 2.5 & $1.8 \mathrm{~b}$ & $1.9 \mathrm{~b}$ & $1.9 \mathrm{~b}$ & $2.1 \mathrm{~b}$ & $2.1 b$ & $2.1 b$ \\
\hline & 5 & $2 b$ & $2 b$ & $2 b$ & $2.2 \mathrm{~b}$ & $2.4 \mathrm{~b}$ & $2.6 \mathrm{~b}$ \\
\hline & Significance & $*$ & $*$ & $*$ & $*$ & $*$ & $*$ \\
\hline \multirow{4}{*}{ Greenhouse } & 0 & - & 1a & 1a & 1a & $1 \mathrm{a}$ & 1a \\
\hline & 2.5 & - & $1.4 \mathrm{~b}$ & $2 b$ & $2.1 \mathrm{~b}$ & $2.2 \mathrm{~b}$ & $2.3 b$ \\
\hline & 5 & - & $1.9 \mathrm{c}$ & $2.3 b$ & $2.6 \mathrm{c}$ & $2.9 \mathrm{~b}$ & $3.4 \mathrm{~b}$ \\
\hline & Significance & - & $*$ & $*$ & $*$ & $*$ & $*$ \\
\hline
\end{tabular}

Different letters in different columns for each condition (shading net or greenhouse) mean statistical differences according to HSD test $(\mathrm{P} \leq 0.05)$, and Kruskal Wallis test. Develoment stages: 1: no change; 2: inner leaves turn red; 3: visible flower bud; 4: anthesis; 5 : senescence of flower bud. 
It was observed that among the plants that were sprayed there were plants with lower accumulation of peltate trichomes, which showed the bright red color later and never reached anthesis. This aspect was not measured in the present study. According to the nursery staff, the presence of red color in this species is enough to enhance plant saleability; the presence of the inflorescences is not necessary. Thus spraying in April with 2.5 or $5 \mathrm{ml} \mathrm{L}^{-1}$ ethephon would acomplish the purpose of increasing plant sales after August of plants growing both under a shading net or in a greenhouse.

\section{Winter experiment}

Again, the unspreayed plants did not show any change. All sprayed plants flowered, however red-colored leaves were not observed. To reach the visible bud stage 662 degree days were needed, and to reach anthesis, 887 degree days; flowering occurred on January 3, 2013. This flowering time matches the flowering time observed in nature (end of spring to the end of autumn), as stated by Reidemann and Aldunate (2011).

\section{Conclusions}

Ethephon triggered the flowering response of Fascicularia bicolor. No change was observed in the unsprayed plants. By spraying in autumn with 2.5 or $5 \mathrm{ml} \mathrm{L}^{-1}$ ethephon, the central bracts turned red in all plants, and later some of them showed the blue central flowers. By spraying with $2.5 \mathrm{ml} \mathrm{L}^{-1}$ ethephon at the end of winter, all plants flowered in the middle of the spring, but the bracts surrounding the flowers kept their original green-greysh coloration. The best flowering results (44\%) were reached by spraying in autumn with $5 \mathrm{ml} \mathrm{L}^{-1}$ ethephon in the plants kept outdoors.

\section{Literature Cited}

Black, R.; Dehgan, B.

1993. Bromeliads. University of Florida-IFAS Extension. Gainesville, FL. USA, 7 p.

Clemson Extension

1995. Hort. L 64. Available: http://www.clemson.edu/psapublishing/ pages/HORT/HORTLF64.PDF Consulted: June 2013.

Dirección Meteorológica de Chile 2013. Anuario climatológico 2012. Santiago, Chile.

L.H. Bailey Hortorium

1976. Hortus Third. Macmillan Publishing Company. New York, S.A., 1290 p.
Riedemann, P. and Aldunate, G.

2011. Flora nativa de valor ornamental, identificación y propagación. Zona sur y austral. Andrés Bello. Santiago, Chile, $732 \mathrm{p}$.

Taiz, L. and Zeiger, E.

2006. Fisiología vegetal. Vol. 2. Ed. Universitat Jaume I. Castelló de la Plana, España, 1338 p.

Zizka, G.; Schmidt, M.; Schulte, K.; Novoa, P.; Pinto, R.;König, K. 2009. Chilean Bromeliaceae: diversity, distribution and evaluation of conservation status. Biodiversity and Conservation, 18: 2449-2471. 
